\title{
VIKING FUND MEDALS AND AWARDS FOR 1958
}

\author{
presented by
}

The Wenner-Gren Foundation for Anthropological Research for Outstanding Achievement in the Field of Anthropology

\section{MEDALIST IN ARCHAEOLOGY chosen by}

The Society for American Archaeology

\section{JESSE D. JENNINGS}

An outstanding talent for administration, significant research in widely diverse areas, and highly effective teaching, have enabled Jesse Jennings to play an important role in the advancement of American archaeology. Hehas developed a strong research and teaching program at the University of Utah, has served as Editor for the Society for American Archaeology, has participated energetically in the Society's affairs, and has played a major part in creating the annual Great Basin Archeological Conference. During his decade with the National Park Service he administered important research and interpretive programs in the Southwest, the Southeast, and the Plains, thus contributing to the intelligent public appreciation of archaeology that is essential to its healthy growth. Jennings began his field research in the Middle West, then shifted to the Southwest, Guatemala, the Southeast, and the Plains. His more recent work in the Great Basin culminated in the 1957 publication of his monograph on Danger Cave, a major

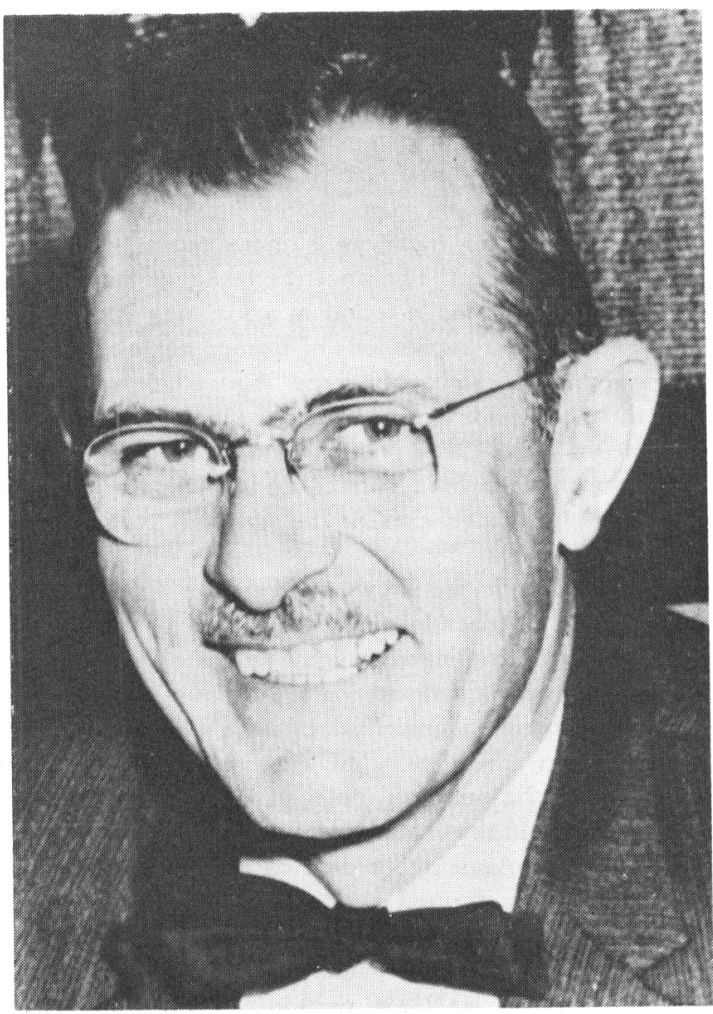

contribution to archaeology which covers a long span of human occupation in a previously littleknown part of the west.

Medalist in General Anthropology, Raymond W. FIRTH Medalist in Physical Anthropology, Henri V. Vallois

\section{PREVIOUS VIKING FUND MEDALISTS IN ARCHAEOLOGY}

\section{A. V. KIDDER, 1946}

J. O. BREW, 1947

Alex D. Krieger, 1948

Hallam L. Movius, JR., 1949

EMIL W. Haury, 1950

Frank H. H. Roberts, JR., 1951
Alfonso Caso, 1952

GoRdon R. WILlEy, 1953

William Duncan Strong, 1954

J. ERIC S. ThOMpson, 1955

Junius BiRd, 1956

JAMES B. GRIFFIN, 1957 